\title{
Interactions between pre- and post-emergence weed harrowing in spring cereals
}

\author{
L O BRANDSÆTER*, K MANGERUD† \& J RASMUSSEN \\ ${ }^{*}$ Bioforsk, Norwegian Institute for Agricultural and Environmental Research, Ås, Norway, †Hedmark University College, Hamar, Norway, \\ and $\$$ Department of Agricultural and Ecology, Faculty of Life Sciences, University of Copenhagen, Taastrup, Denmark
}

Received 20 December 2011

Revised version accepted 10 April 2012

Subject Editor: Peter Zwerger, JKI, Germany

\section{Summary}

Pre- and post-emergence weed harrowing were studied in spring cereals in different environments and with two types of harrows in Norway during 2004-2006. The objectives were to investigate interactions between preand post-emergence weed harrowing and the importance of harrow type. We hypothesised that pre- and post-emergence harrowing interact positively, that a combination gives more stable weed control effects than pre- and post-emergence weed harrowing used alone, and that a harrow type with bent tines is more aggressive and suitable on hard-packed soils than a harrow with strait tines. The results only supported the last of these hypotheses. Post-emergence weed harrowing controlled a certain percentage of the present weeds, and this percentage was not dependent on pre-emergence weed harrowing. On average, pre-emergence harrowing reduced weed density by $26 \%$ and weed biomass by $22 \%$, while the average effect of postemergence harrowing was $47 \%$ on weed density and $41 \%$ on weed biomass. The combined effect of pre- and post-emergence weed harrowing was $61 \%$ on weed density and $54 \%$ on weed biomass. The combination did not give more stable weed control effects than preand post-emergence weed harrowing used alone. Preemergence harrowing increased the average crop yield by $6.2 \%$, post-emergence harrowing by $4.0 \%$ and the combined effect was $10 \%$. Crop yield was mainly increased on hard-packed soils. Weed and crop responses varied strongly among experiments, but the efficacy of pre- and post-emergence weed harrowing was positively correlated across experiments. Weed species composition was of minor importance regarding weed control. The study indicates that one aggressive postemergence cultivation may be as good as one preemergence and one less aggressive post-emergence cultivation. However, little is known about the interactions between cultivation at different crop and weed growth stages.

Keywords: integrated weed management, machinery, mechanical weed control, non-herbicide weed management, organic farming.

Brandseter LO, Mangerud K \& Rasmussen J (2012) Interactions between pre- and post-emergence weed harrowing in spring cereals. Weed Research 52, 338-347.

\section{Introduction}

In Scandinavia, weed harrowing has been used to control weed seedlings in cereals since the beginning of the 20th century. Harrowing was recommended in the first half of the twentieth century because field experiments showed efficient weed control and increased crop yields. Korsmo (1926) summarised 55 Norwegian field experiments in spring cereals in 1919-1920 and reported that the weed control effect of pre-emergence weed harrowing averaged $53 \%$ and that the combined weed control effect of pre- and post-emergence

Correspondence: Jesper Rasmussen, Department of Agriculture and Ecology, Faculty of Life Sciences, University of Copenhagen, Højbakkegaard Allé 9, DK-2630 Taastrup, Denmark. Tel: (+45) 353334 56; Fax: (+45) 353333 84; E-mail: jer@life.ku.dk 
harrowing averaged $81 \%$. The corresponding increases in grain yield averaged $16 \%$ for pre-emergence harrowing and $29 \%$ for the combination of pre- and post-emergence harrowing. Another review of old experiments showed similar grain yield responses (Rydberg, 1985).

In the old experiments, pre-emergence weed harrowing was carried out just before crop emergence and post-emergence was carried out when cereals had 2-3 leaves. The same approach is used today, but harrows are now modern flex-tine harrows (Van Der Schans et al., 2006). The old experiments were carried out with rigid-tine types of harrows, which were commonly used in Scandinavia up to the 1950s (Rydberg, 1985; Rasmussen, 1992).

Rasmussen (1992) showed that rigid-tine and flex-tine harrows are active through the same mode of operation and cannot be separated in terms of crop-weed selectivity, where selectivity is defined as the ratio between percentage weed control and percentage crop burial in soil immediately after harrowing. The crop burial measure (also called crop soil cover) expresses the immediate crop response associated with post-emergence harrowing. The selectivity concept ignores uprooting of crop plants, because uprooting is considered negligible for strongly anchored crops such as cereals (Jensen et al., 2004), even if it is acknowledged to play a role with weakly anchored plants (Kurstjens \& Kropff, 2001).

After the Second World War, herbicides gradually outcompeted weed harrowing. Research on harrowing almost stopped in Scandinavia until the emergence of organic agriculture in the 1980s. In Norway, conventional farmers are now subsidised to use weed harrows instead of herbicides in some areas, to protect the environment (Fylkesmannen i Oslo og Akershus, 2011). Besides weed control, weed harrowing may also have other positive impacts on crops, such as breaking the soil crust. In areas with heavy soils, the main benefit of weed harrowing is ascribed to soil loosening if a soil crust is present (Mangerud, 2006). Canadian trials showed that cultivating tillage with a rotary hoe in weed-free soyabean (Glycine max (L.) Merr.) increased crop yield (Leblanc \& Cloutier, 2001).

Field experiments with weed harrowing in the herbicide era have not shown the same convincing results, in terms of crop yield, as experiments in the pre-herbicide era. This is probably due to a tremendous increase in agricultural productivity, improved crop competition and changes of weed flora (Andreasen \& Streibig, 2011). Many competitive dicotyledons (e.g. Sinapis arvensis L. and Brassica napus ssp. campestris (L.) A.R.) have been effectively controlled since the breakthrough of auxin herbicides and are now less common. In organic agriculture, this might be different because weed species susceptible to herbicides are much more common (Hyvönen et al., 2003), although many reports have shown that positive crop yield responses are rare in experiments with weed harrowing in organic crops (Dierauer, 1990; Lundkvist, 2009; Rasmussen et al., 2010; Johnson \& Holm, 2010).

Lack of positive crop yield responses might be due to low weed competition and/or crucial crop damages associated with harrowing. Many studies have focused on post-emergence weed harrowing and the associated crop damages (Jensen et al., 2004; Rasmussen et al., 2010), whereas the competitive ability of weeds and thereby the need for weed control is seldom quantified in experiments with weed harrowing (Rueda-Ayala et al., 2011).

Pre-emergence weed harrowing has been the subject of only limited research, but has proven to be effective against early emerging weed species under Scandinavian growing conditions (Lundkvist, 2009). However, under other growing conditions, pre-emergence harrowing has proven to be without any effect, because of lack of weed germination at the time of cultivation (Johnson \& Holm, 2010). Pre-emergence harrowing may also stimulate flushes of new weed seedlings (Kees, 1962), which makes it difficult to predict the effects of pre-emergence weed harrowing. Rasmussen (1996) showed that the results of pre-emergence harrowing may depend on the dynamic patterns of weed and crop germination and that preemergence weed harrowing only can be expected to be effective if the majority of weeds germinate earlier than the crop.

The objectives of this study were to investigate the possible benefits from pre-emergence weed harrowing in spring cereals, the interactions between pre- and postemergence weed harrowing and the importance of harrow type. It was hypothesised that pre- and postemergence harrowing interacts through synergism and that the combination gives more stable weed control effects than pre- and post-emergence weed harrowing used alone. The assumption behind this hypothesis is that pre-emergence weed harrowing increases the chances for efficient post-emergence weed harrowing. If weeds germinate early, pre-emergence harrowing is expected to control the earliest emerging weeds, which are supposed to be more difficult to control by postemergence harrowing than late emerging weeds. If weeds germinate late, pre-emergence harrowing is expected to have low efficiency, but post-emergence harrowing is still expected to be efficient, because of late weed emergence and small weeds at the 2-4 leaf growth stage of cereals. Because of the risks of hard-packed and/or crusted soils and thereby difficult conditions for weed harrowing, two different types of harrows were tested in the experiments: one with long, straight tines and one with short, bent 
tines. It was hypothesised that bent tines are more aggressive, resulting in higher weed control effects on hard-packed or crusted soils.

\section{Materials and methods}

\section{Experiments}

A total of eight experiments were carried out from 2004 to 2006 at three different locations in Norway (Table 1).

Three experiments were carried out at the Norwegian University of Life Sciences, Ås $\left(59^{\circ} 40^{\prime} \mathrm{N}, 10^{\circ} 46^{\prime} \mathrm{E}, 90 \mathrm{~m}\right.$ a.s.1.) in spring barley (Hordeum vulgare L.) on a loamsandy soil. Three experiments were carried out at Stange $\left(60^{\circ} 67^{\prime} \mathrm{N}, 11^{\circ} 21^{\prime} \mathrm{E}, 210 \mathrm{~m}\right.$ a.s.1.) in spring barley on a gravely morainic loam soil, and two experiments were carried out at Bjørkelangen $\left(59^{\circ} 55^{\prime} \mathrm{N}, 11^{\circ} 34^{\prime} \mathrm{E}, 132 \mathrm{~m}\right.$

Table 1 Dates of field operations and weed and crop assessments

\begin{tabular}{|c|c|c|c|}
\hline & \multicolumn{3}{|c|}{ Location experiment } \\
\hline & 2004 & 2005 & 2006 \\
\hline & \multicolumn{3}{|l|}{ As } \\
\hline & 1 & 2 & 3 \\
\hline Seedbed preparation & 3 May & 20 April & 4 May \\
\hline Sowing & 3 May & 21 April & 5 May \\
\hline $\begin{array}{l}\text { Pre-emergence weed } \\
\text { harrowing }\end{array}$ & 10 May & 1 May & 11 May \\
\hline $\begin{array}{l}\text { Post- emergence } \\
\text { weed harrowing }\end{array}$ & 27 May & 24 May & 29 May \\
\hline Weed assessment & 11 June & 15-17 June & 20-21 June \\
\hline \multirow[t]{3}{*}{ Crop harvest } & 21 August & 12 August & 8 August \\
\hline & \multicolumn{3}{|l|}{ Bjørkelangen } \\
\hline & 4 & \multicolumn{2}{|l|}{5} \\
\hline Seedbed preparation & 8-9 May & \multicolumn{2}{|l|}{12 May } \\
\hline Sowing & 10 May & \multicolumn{2}{|l|}{13 May } \\
\hline $\begin{array}{l}\text { Pre-emergence weed } \\
\text { harrowing }\end{array}$ & 16 May & \multicolumn{2}{|l|}{3 June* } \\
\hline $\begin{array}{l}\text { Post- emergence } \\
\text { weed harrowing }\end{array}$ & 14 June & \multicolumn{2}{|l|}{20 June } \\
\hline Weed assessment & 28 June & \multirow{2}{*}{\multicolumn{2}{|c|}{$\begin{array}{l}19 \text { July } \\
9 \text { September }\end{array}$}} \\
\hline \multirow[t]{3}{*}{ Crop harvest } & 9 September & & \\
\hline & \multicolumn{3}{|l|}{ Stange } \\
\hline & 6 & 7 & 8 \\
\hline Seedbed preparation & 11 May & 13 May & 8-9 May \\
\hline Sowing & 12 May & 13 May & 10 May \\
\hline $\begin{array}{l}\text { Pre-emergence weed } \\
\text { harrowing }\end{array}$ & 18 May & 23 May & $28 \mathrm{May}^{*}$ \\
\hline $\begin{array}{l}\text { Post- emergence } \\
\text { weed harrowing }\end{array}$ & 4 June & 10 June & 10 June \\
\hline Weed assessment & 18 June & 29 June & 28 June \\
\hline Crop harvest & 23 August & 31 August & 26 August \\
\hline
\end{tabular}

* Delayed because of rain, weed harrowing at 1-2 leaf stage. a.s.1.) in oats (Avena sativa L.) on a clay loam soil. Three additional experiments were also planned at Bjørkelangen, but because of rain and wet soil conditions, it was not possible to accomplish timely treatments in 2006, which resulted in two experiments only.

Spring barley (cv. Kinnan) at $\AA$ s and Stange (cv. Edel) was grown conventionally and fertilised annually with $95 \mathrm{~kg} \mathrm{~N} \mathrm{ha}^{-1}$ and $18 \mathrm{~kg} \mathrm{P} \mathrm{ha}^{-1}$. Crop rotations were dominated by cereals at $\AA^{\circ}$ and by cereals and leys at Stange. Spring oats (cv. Belinda) at Bjørkelangen were grown organically and not fertilised, but green manure was grown every fourth year to maintain soil fertility. Red clover (Trifolium pratense L.) or white clover (Trifolium repens L.) was undersown to fix nitrogen, but there was no undersowing in the experimental plots because of harrowing.

All experimental plots were ploughed in early November, and the seedbed was prepared in the following spring. Approximately 350 seeds $\mathrm{m}^{-2}$ were sown in spring barley and 400 seeds $\mathrm{m}^{-2}$ in spring oat. Row width was $12.5 \mathrm{~cm}$ and plots were rolled with a Cambridge roller after sowing and before pre-emergence weed harrowing. Plots were 1.5 by $10 \mathrm{~m}$ and the net area, which was combine harvested, measured 1.5 by $6 \mathrm{~m}$. A wide-frame tractor was used, which allowed for traffic-free plots from sowing to harvest. Normal precipitation in the growing season (May-September) is $382 \mathrm{~mm}$ at $\AA \mathrm{s}, 336 \mathrm{~mm}$ at Bjørkelangen and $313 \mathrm{~mm}$ at Stange, and mean temperatures in the growing season are $13.3,12.7$ and $12.5^{\circ} \mathrm{C}$ respectively. Precipitation before and after weed harrowing is specified in Table 2 .

\section{Treatments}

All experiments were with three factors, each at two levels, and three block replications, giving 24 plots per experiment. The experiments were carried out with a completely randomised factorial design. Factors were type of harrow (straight and bent tines), pre-emergence weed harrowing (with and without) and post-emergence weed harrowing (with and without). The two harrows were (i) the CMN harrow (CMN Maskintec, Thyholm, Denmark), which represents harrows with long $(650 \mathrm{~mm})$ and straight tines and (ii) the Einböck harrow (Einböck, Dorf an der Pram, Austria), which represents harrows with short $(450 \mathrm{~mm})$ and bent tines. The tines of the CMN harrow can be adjusted from vertical $\left(90^{\circ}\right)$ to $45^{\circ}$ backwards, and the tines of the Einböck harrow can also be adjusted in forward angles to make it more aggressive. The distance between tines was $50 \mathrm{~mm}$ on the CMN harrow and $25 \mathrm{~mm}$ on the Einböck harrow.

Pre- and post-emergence weed harrowing were carried out with $1.5 \mathrm{~m}$ wide harrows. Driving speed was $12 \mathrm{~km} \mathrm{~h}^{-1}$ for the Einböck harrow and $16 \mathrm{~km} \mathrm{~h}^{-1}$ for 
Table 2 Shear strength and soil moisture before pre- and post-emergence weed harrowing, precipitation before and after weed harrowing and density of dominating weed species in uncultivated plots

\begin{tabular}{|c|c|c|c|c|c|c|c|c|c|c|c|}
\hline \multirow[b]{3}{*}{ Experiment } & \multicolumn{2}{|c|}{$\begin{array}{l}\text { Shear } \\
\text { strength } \\
(\mathrm{kPa})\end{array}$} & \multicolumn{2}{|c|}{$\begin{array}{l}\text { Soil } \\
\text { moisture } \\
\text { (volume \%) }\end{array}$} & \multicolumn{6}{|c|}{ Precipitation* (mm) } & \multirow[b]{3}{*}{ Weed species $\left(\mathrm{m}^{-2}\right)$} \\
\hline & \multirow[b]{2}{*}{ Pre } & \multirow[b]{2}{*}{ Post } & \multirow[b]{2}{*}{ Pre } & \multirow[b]{2}{*}{ Post } & \multicolumn{3}{|l|}{ Pre } & \multicolumn{3}{|c|}{ Post } & \\
\hline & & & & & -2 & 0 & 2 & -2 & 0 & 2 & \\
\hline 1 & 12.6 & 7.5 & 14.6 & 12.0 & 0 & 0 & 5.6 & 3.4 & 0 & 2.8 & $\begin{array}{l}\text { Matricaria discoidea DC. (189) } \\
\text { Chenopodium album L. (73) }\end{array}$ \\
\hline 2 & 5.2 & 8.5 & 16.1 & 28.5 & 8.6 & 0 & 4 & 3.8 & 0.2 & 10.8 & $\begin{array}{l}\text { C. album L. (99) } \\
\text { Lamium purpureum L. (85) }\end{array}$ \\
\hline 3 & 3.5 & 18.8 & 19.7 & 24.5 & 0 & 0 & 0 & 0 & 1.2 & 0.4 & $\begin{array}{l}\text { C. album L. (346) } \\
\text { Fumaria officinalis L. (85) } \\
\text { Viola arvensis Murr. (83) } \\
\text { Lamium purpureum L. (65) } \\
\text { Thlaspi arvense L. (59) } \\
\text { Galeopsis tetrahit L. (14) }\end{array}$ \\
\hline 4 & 22.0 & 24.7 & 19.8 & 14.7 & 0.1 & 0 & 0 & 0 & 0 & 0.4 & $\begin{array}{l}\text { (very few weeds, no dominating } \\
\text { species) }\end{array}$ \\
\hline 5 & 8.9 & 19.0 & 25.4 & 20.4 & 0 & 0.5 & 7 & 0.1 & 0 & 0.1 & $\begin{array}{l}\text { Polygonum persicaria L. (127) } \\
\text { Polygonum aviculare L. (54) } \\
\text { Lamium purpureum L. (27) }\end{array}$ \\
\hline 6 & 2.4 & 3.8 & 15.2 & 10.7 & 0 & 0 & 2.3 & 0 & 0 & 0 & $\begin{array}{l}\text { C. album L. (70) } \\
\text { Stellaria media (L.) Vill. (41) } \\
\text { Polygonum persicaria L. (12) } \\
\text { Polygonum aviculare L. (11) }\end{array}$ \\
\hline 7 & 3.8 & 5.4 & 19.8 & 13.1 & 11.6 & 2 & 3.8 & 0 & 0 & 25.4 & $\begin{array}{l}\text { C. album L. (97) } \\
\text { Stellaria media (L.) Vill. (16) } \\
\text { Polygonum aviculare L. (13) }\end{array}$ \\
\hline 8 & 8.0 & 11.0 & 19.4 & 10.6 & 0 & 0.2 & 0 & 0 & 0 & 0 & $\begin{array}{l}\text { C. album L. (219) } \\
\text { Stellaria media (L.) Vill. (61) } \\
\text { Polygonum aviculare L. (34) } \\
\text { Viola arvensis Murr. (32) } \\
\text { Thlaspi arvense L. (12) }\end{array}$ \\
\hline
\end{tabular}

*Precipitation on the 2 days before weed harrowing $(=-2)$, the day of harrowing $(=0)$ and on the 2 days after weed harrowing $(=2)$.

the CMN harrow. The higher driving speed for the CMN harrow was in accordance with a recommendation from the manufacturer. The tine angle and wheel depth (on harrows) were adjusted to achieve the desirable harrowing depth of $20 \mathrm{~mm}$ at very low speed $\left(\approx 1 \mathrm{~km} \mathrm{~h}^{-1}\right)$. Adjustments were carried out in plots that had not previously been harrowed. Pre-emergence harrowing was carried out as close to crop emergence as practically possible and post-emergence harrowing was carried out at the 3-4 leaf stage of cereals (Table 1). Preand post-emergence harrowing were both carried out along crop rows.

\section{Crop, weed and soil assessments}

Weed density and weed biomass were assessed in all experiments at growth stage 49 of cereals according to the Zadoks scale (Zadoks et al., 1974). Weed density was counted in four randomly selected $0.125 \mathrm{~m}^{2}$ subplots $(0.50$ by $0.25 \mathrm{~m})$ in each plot. The density of the dominating weed species were counted separately and the remaining weeds were pooled to calculate the total number of weeds per $\mathrm{m}^{2}$ (Table 2). The total weed biomass was harvested in the same subplots and weed dry matter was estimated after drying at $80^{\circ} \mathrm{C}$ for $72 \mathrm{~h}$. Grain yield was harvested from $1.5 \times 6 \mathrm{~m}$ subplots by a combine harvester from early August to early September (Table 1). Grain samples were dried and yield was recorded, based on $15 \%$ water content.

To evaluate the degree of hard-packed and/or crusted soils, shear strength was measured with a 'Vane shear auger' before pre- and post-emergence weed harrowing. The Vane shear auger tool consists of two thin metal blades attached to a vertical shaft. The test was carried out by pushing the tester into the soil $(3 \mathrm{~cm}$ depth) and applying a torque to the vertical shaft. In each experiment, 45 measurements were taken before pre- and post-emergence in control plots without harrowing (Table 2). Measurements were taken outside the net-plots where weeds and yield were recorded. 
Soil moisture was measured using a soil moisture sensor (ThetaProbe soil moisture sensor, Type ML1UM-2; AT Delta-T Devices Ltd, Cambridge, UK). The soil moisture measurement were taken with 15 measuring points in each block (45 measurements in each experiment), immediately before weed harrowing.

\section{Statistics}

Analysis of variance was performed with PROC MIXED in SAS (SAS version 9.1; SAS Institute, Cary, NC, USA). Mixed models with fixed and random effects were used, because block was considered random. All response variables, weed density, weed biomass and crop yield were log-transformed to stabilise variance. For each response variable, all data were analysed in one model with number of experiment, type of harrow, pre-emergence harrowing and post-emergence harrowing as fixed effects and block effects as random. Two-way, three-way and four-way interactions were analysed in the full four-way analysis of variance. Experiments were also analysed individually, because of significant interactions between experiment and experimental treatments. A mixed model with pre- and post-emergence harrowing as fixed effects and block effects as random was used. To test whether different weed species responded differently to harrowing, experiments $1-8$ were analysed separately. Weed density was analysed in a mixed model with weed species, pre-emergence and post-emergence harrowing as fixed factors. Type of harrow and block effects were considered random.

To evaluate the weed harrowing effects and the precision of the estimated effects, differences of the least squares means (LS-means) and the corresponding $95 \%$ confidence intervals $(95 \%$-CI) were estimated. As all response variables were log-transformed, the backtransformed difference between two levels of either preemergence weed harrowing or post-emergence weed harrowing reflects the multiplicative effects of harrowing. For example, if the difference of LS-means for weed density in plots that have been harrowed and plots that have not is -0.883 , the effect of harrowing is $100(1-\exp (-0.883))=58,6 \%$. To visualise and analyse the interactions between pre- and post-emergence weed harrowing, main effects (\%) of postemergence weed harrowing were plotted against main effects $(\%)$ of pre-emergence weed harrowing, and the relationship was subjected to linear regression. Each observation represented one experiment (no block replications). Linear regression was used to analyse how shear strength influenced weed control. Percentage weed control was the response variable, and shear strength and type of harrow were the independent variables.

\section{Results}

\section{Interaction between pre- and post-emergence cultivation}

The interaction between pre- and post-emergence weed harrowing was not influenced by the type of harrow for either weed density, weed biomass or crop yield (Table 3). The log-transformed data indicate that preand post-emergence weed harrowing have multiplicative effects. If post-emergence weed harrowing controls $60 \%$ of the weeds without preceding weed harrowing, it will also control $60 \%$ of the present weeds in plots that have been harrowed before crop emergence. Hence, if preemergence weed harrowing controls $40 \%$ of the weeds and post-emergence harrowing controls $60 \%$ of the weeds, the combined effect will be $84 \%$.

On average, the main effect of pre-emergence harrowing was 26\% (95\%-CI: 16-36\%) $(P<0.001)$ weed density decline and 22\% (95\%-CI: 10-33\%) weed biomass decline. The average effect of post-emergence harrowing was 47\% (95\%-CI: 37-51\%) weed density decline and 41\% (95\%-CI: 31-49\%) weed biomass decline. The combined effect of pre- and post-emergence weed harrowing was $61 \%(95 \%-\mathrm{CI}: 53-68 \%)$ on weed density and 54\% (95\%-CI: 43-60\%) on weed biomass. The performance of pre- and post-emergence weed harrowing, however, varied between different experiments (Table 3). The interaction between pre- and postemergence weed harrowing was also influenced by experiment (three-way interactions) (Table 3). Therefore,

Table 3 AnOva table with $P$-values for the analysis of weed and crop responses

\begin{tabular}{|c|c|c|c|c|}
\hline \multirow[b]{2}{*}{ Fixed effects } & \multirow[b]{2}{*}{ d.f. } & \multicolumn{3}{|l|}{$P$-value } \\
\hline & & $\begin{array}{l}\text { Total } \\
\text { weed } \\
\text { density }\end{array}$ & $\begin{array}{l}\text { Weed } \\
\text { biomass }\end{array}$ & $\begin{array}{l}\text { Crop } \\
\text { yield }\end{array}$ \\
\hline Harrow $(\mathrm{H})$ & 1 & 0.0106 & 0.0214 & 0.1386 \\
\hline $\begin{array}{l}\text { Pre-emergence } \\
\text { (Pre) }\end{array}$ & 1 & $<0.0001$ & $<0.0001$ & 0.0003 \\
\hline $\begin{array}{l}\text { Post-emergence } \\
\text { (Post) }\end{array}$ & 1 & $<0.0001$ & $<0.0001$ & 0.0165 \\
\hline Experiment (E) & 7 & $<0.0001$ & $<0.0001$ & $<0.0001$ \\
\hline $\mathrm{H} \times$ Pre & 1 & 0.7899 & 0.8792 & 0.0128 \\
\hline $\mathrm{H} \times$ Post & 1 & 0.0323 & 0.3503 & 0.3882 \\
\hline $\mathrm{H} \times \mathrm{E}$ & 7 & 0.2597 & 0.0486 & 0.7563 \\
\hline Pre $\times$ Post & 1 & 0.1667 & 0.1783 & 0.2670 \\
\hline Pre $\times E$ & 7 & 0.0105 & 0.0003 & $<0.0001$ \\
\hline Post $\times \mathrm{E}$ & 7 & 0.2532 & 0.0049 & 0.0017 \\
\hline $\mathrm{H} \times$ Post $\times$ Pre & 1 & 0.4885 & 0.2148 & 0.8578 \\
\hline $\mathrm{H} \times \mathrm{E} \times$ Pre & 7 & 0.9451 & 0.5694 & 0.3219 \\
\hline $\mathrm{H} \times \mathrm{E} \times$ Post & 7 & 0.0300 & 0.2022 & 0.3411 \\
\hline$E \times$ Pre $\times$ Post & 7 & 0.0028 & $<0.0001$ & 0.1108 \\
\hline $\mathrm{E} \times$ Pre $\times$ Post $\times \mathrm{H}$ & 7 & 0.3190 & 0.7110 & 0.9462 \\
\hline
\end{tabular}


weed control effects for each experiment are shown in Tables 4 and 5. Pre-emergence weed control effects varied from about $50 \%$ to non-significant effects (positive and negative) and post-emergence weed control effects varied from about $60 \%$ to non-significant effects (Tables 4 and 5).

The three-way $\mathrm{E} \times$ Pre $\times$ Post interaction in Table 3 shows that the effect of post-emergence harrowing was influenced by the effect of pre-emergence harrowing in a site-specific way. This is illustrated in Fig. 1, which shows a linear positive correlation between the weed control effects of pre-emergence harrowing. This applies for both weed control calculated on the basis of weed density $\left(r=0.936^{* * *}\right)$ and weed biomass $\left(r=0.923^{* * *}\right)$. Sites resulting in high effects of pre-emergence harrowing also resulted in high effects of post-emergence harrowing. There were no indications that the combination of preand post-emergence weed harrowing stabilised the weed control effects (Tables 4 and 5).

Experiment 4 showed the lowest weed control effect, and weed biomass was even increased after the combination of pre- and post-emergence weed harrowing (Table 5). At the same time, Experiment 4 was characterised by soil with high shear strength (Table 2), low weed density in untreated plots (Table 4) and insignificant amounts for weed biomass (Table 5).
Table 4 Weed density in untreated plots and predicted main effects of pre-emergence and post-emergence weed harrowing and the combined effect of pre- and post-emergence weed harrowing $(95 \%$ confidence intervals in parentheses)
Table 5 Weed biomass in untreated plots and predicted main effects of pre-emergence and post-emergence weed harrowing and the combined effect of pre- and post-emergence weed harrowing $(95 \%$ confidence intervals in parentheses)
Fig. 1 Relationship between main effects of pre- and post-emergence weed harrowing calculated on the basis of weed density (A) and weed biomass (B).

\begin{tabular}{|c|c|c|c|c|}
\hline \multirow[b]{2}{*}{ Experiment } & \multirow{2}{*}{$\begin{array}{l}\text { Weed density } \\
\text { in untreated } \\
\text { plots }\left(\mathrm{g} \mathrm{m}^{-2}\right)\end{array}$} & \multicolumn{3}{|l|}{ Weed control (\%) } \\
\hline & & $\begin{array}{l}\text { Pre-emergence } \\
\text { harrowing }\end{array}$ & $\begin{array}{l}\text { Post-emergence } \\
\text { harrowing }\end{array}$ & Combined effect \\
\hline 1 & 332 & $49(25 \text { to } 66)^{* * *}$ & $59(39 \text { to } 72)^{* * *}$ & $78(54 \text { to } 89)^{* * *}$ \\
\hline 2 & 278 & $-6(-54 \text { to } 28)^{N S}$ & $29(-4 \text { to } 50)^{N S}$ & $24(-12 \text { to } 48)^{N S}$ \\
\hline 3 & 689 & $27(-7 \text { to } 50)^{\mathrm{NS}}$ & $43(18 \text { to } 60)^{* *}$ & $59(37 \text { to } 75)^{* * *}$ \\
\hline 4 & 27 & $-22(-80 \text { to } 17)^{\mathrm{NS}}$ & $27(-5 \text { to } 50)^{N S}$ & $11(-37 \text { to } 42)^{\mathrm{NS}}$ \\
\hline 5 & 239 & $51(29 \text { to } 67)^{* * *}$ & $56(37 \text { to } 70)^{* * *}$ & $79(63 \text { to } 88)^{* * *}$ \\
\hline 6 & 157 & $24(-15 \text { to } 50)^{N S}$ & $54(29 \text { to } 70)^{* * *}$ & $64(14 \text { to } 85)^{*}$ \\
\hline 7 & 135 & $29(-4 \text { to } 52)^{N S}$ & 53 (32 to 67$) * * *$ & $67(46 \text { to } 79)^{* * *}$ \\
\hline 8 & 363 & $30(-2 \text { to } 53)^{N S}$ & $46(30 \text { to } 63)^{* * *}$ & $63(29 \text { to } 81)^{* * *}$ \\
\hline
\end{tabular}

$* P<0.05 ; * * P<0.01 ; * * * P<0.001 ;$ NS, non-significant $(P>0.05)$.

\begin{tabular}{|c|c|c|c|c|}
\hline \multirow[b]{2}{*}{ Experiment } & \multirow{2}{*}{$\begin{array}{l}\text { Weed biomass } \\
\text { in untreated } \\
\text { plots }\left(\mathrm{m}^{-2}\right)\end{array}$} & \multicolumn{3}{|l|}{ Weed control (\%) } \\
\hline & & $\begin{array}{l}\text { Pre-emergence } \\
\text { harrowing }\end{array}$ & $\begin{array}{l}\text { Post-emergence } \\
\text { harrowing }\end{array}$ & Combined effect \\
\hline 1 & 8.9 & $51(32 \text { to } 65)^{* * *}$ & $45(22 \text { to } 61)^{* * *}$ & $73(52 \text { to } 85)^{* * *}$ \\
\hline 2 & 6.1 & $-2.0(-43 \text { to } 28)^{\mathrm{NS}}$ & $20(-13 \text { to } 43)^{\mathrm{NS}}$ & $19(-16 \text { to } 42)^{\mathrm{NS}}$ \\
\hline 3 & 47.9 & $29(0 \text { to } 49)^{\mathrm{NS}}$ & $31(16 \text { to } 58)^{* *}$ & $58(37 \text { to } 71)^{* * *}$ \\
\hline 4 & 0.3 & $-31(-83 \text { to } 7)^{\mathrm{NS}}$ & $-7(-48 \text { to } 27)^{N S}$ & $-46(-96 \text { to } 0)^{*}$ \\
\hline 5 & 14.0 & $45(22 \text { to } 60)^{* * *}$ & $53(34 \text { to } 66)^{* * *}$ & $74(60 \text { to } 83)^{* * *}$ \\
\hline 6 & 29.2 & $29(-1 \text { to } 51)^{N S}$ & $56(38 \text { to } 70)^{* * *}$ & $68(33 \text { to } 84)^{* * *}$ \\
\hline 7 & 7.8 & $34(1 \text { to } 53)^{*}$ & $44(21 \text { to } 60)^{* * *}$ & $63(36 \text { to } 79)^{* * *}$ \\
\hline 8 & 21.6 & $13(-22 \text { to } 32)^{\mathrm{NS}}$ & $22(-10 \text { to } 44)^{N S}$ & $32(-30 \text { to } 63)^{N S}$ \\
\hline
\end{tabular}

$* P<0.05 ; * * P<0.01 ; * * * P<0.001 ;$ NS, non-significant $(P>0.05)$.
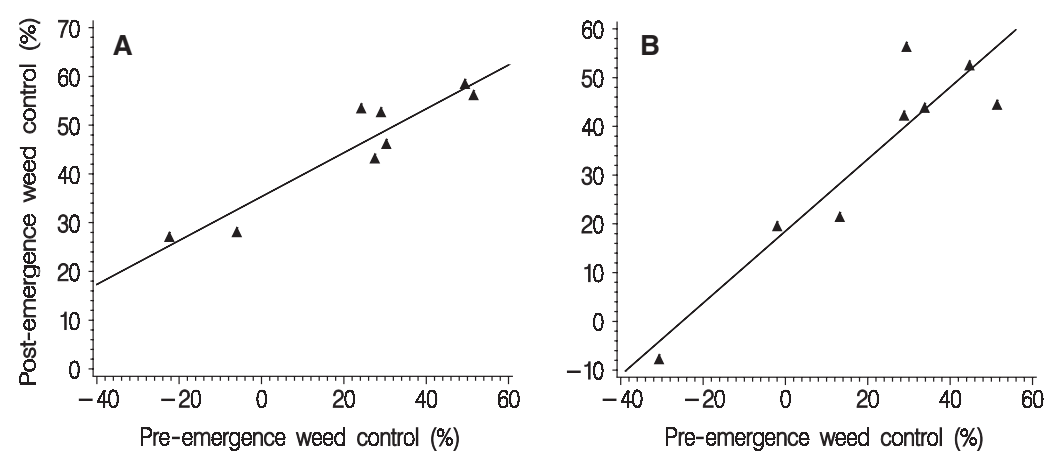


\section{Type of harrow and soil shear strength}

The average weed density was 16\% (95\%-CI: 5-27\%) lower in plots that were harrowed with the Einböck harrow, as compared with the CMN harrow $(P<0.05)$, and the weed biomass was 13\% (95\%-CI: 2-23\%) lower $(P<0.05)$ (data not shown). A significant interaction between type of harrow and post-emergence weed harrow showed that the Einböck harrow only gave higher weed control effects than the CMN harrow when it was used post-emergence $(P<0.05)$, whereas there were no significant differences between harrows when they were used pre-emergence (Table 3). The Einböck harrow reduced the weed density by $54 \%$ (95\%-CI: $48-59 \%$ ) when used postemergence, whereas the CMN reduced the weed density by 39\% (95\%-CI: 27-47\%). The corresponding values for weed biomass were $48 \%$ (95\%-CI: $35-58 \%)$ and $33 \%$ (95\%-CI: $16-46 \%$ ), respectively, but this difference was not statistically significant (Table 3 ).

An interaction between type of harrow and preemergence harrowing (Table 3) revealed that the Einböck harrow improved the average yield by $10.1 \%$ (95\%-CI: 5.7-14.3\%) when it was used pre-emergence, whereas there was no yield effect after pre-emergence harrowing with the CMN harrow $(P=0.40)$ (data not shown). There was no difference between harrows in terms of crop yield response for post-emergence harrowing (Table 3 ).

Regression analysis showed that the CMN harrow was more sensitive to soils with high shear strength (hardpacked and/or crusted soils) (Table 2) than the Einböck harrow. Weed control (calculated on the basis of weed density) declined by $2.6 \%$ (95\%-CI: $0.1-3.4 \%)$ for each unit of increase in shear resistance $(P=0.042)$, whereas weed control was unaffected by the shear strength when the Einböck harrow was used $(P=0.796)$.

\section{Weed species}

In general, the different weed species responded similarly to weed harrowing (Table 6). Interaction between weed species and harrowing was only found for pre-emergence weed harrowing in Experiment 1, where Chenopodium album L. was unaffected by pre-emergence harrowing $(P=0.96)$ and Matricaria discoidea DC. was reduced by $89 \%(95 \%$-CI: $76-95 \%)$.

Two weed species, C. album and Polygonum aviculare, appeared in three experiments (Experiments. 6-8). When these experiments were analysed together, only C. album was influenced by weed harrowing. Polygonum aviculare did not respond to either pre-emergence or post-emergence harrowing. The average effect of preemergence harrowing on C. album was 36\% (95\%-CI: $5-58 \%$ ) and the average effect of post-emergence harrowing was $62 \%(95 \%-\mathrm{CI}: 43-71 \%)$.

\section{Crop yield}

Pre-emergence harrowing increased the average crop yield by $6.2 \%$ (95\%-CI: 2.9-9.2\%), post-emergence harrowing increased yield by $4.0 \% \quad(95 \%-\mathrm{CI}: 0.8-$ $7.2 \%)$, and the combined effect was $10 \%(95 \%-\mathrm{CI}$ : $3.5-12.1 \%$ ). However, the yield effects were strongly influenced by experiment, as shown in Table 7 . When experiments were analysed separately, only Experiments 1 and 4 showed significant yield increase due to harrowing. Both experiments were characterised by hard-packed soils and low yields in untreated plots. Experiment 4 was furthermore characterised by low weed density (Table 4) and low weed biomass (Table 5) in untreated plots. When the experiments without hardpacked and crusted soils were analysed together, weed harrowing had no impact on crop yield either for preemergence harrowing $(P=0.27)$ or post-emergence harrowing $(P=0.74)$, and there were no interactions between pre- and post-emergence harrowing $(P=0.95)$.

\section{Discussion}

The experiments did not support the hypothesis that post-emergence weed harrowing is more efficient if it is preceded by pre-emergence harrowing. Synergism

\begin{tabular}{lllllllll}
\hline \multicolumn{7}{c}{ Experiment number } \\
\cline { 2 - 8 } Fixed effects & 1 & 2 & 3 & 5 & 6 & 7 & 8 \\
\hline Species (S) & 0.2164 & 0.5470 & $<0.0001$ & 0.0747 & $<0.0001$ & $<0.0001$ & $<0.0001$ \\
$\begin{array}{l}\text { Pre-emergence } \\
\quad \text { Pre) }\end{array}$ & 0.0002 & 0.4347 & 0.1381 & 0.0099 & 0.0175 & 0.4840 & 0.0063 \\
Post-emergence & $<0.0001$ & $<0.0001$ & $<0.0001$ & $<0.0001$ & 0.0006 & 0.0026 & $<0.0001$ \\
$\quad \begin{array}{l}\text { Post) } \\
\text { Pre } \times \text { Post }\end{array}$ & 0.4549 & 0.5848 & 0.4656 & 0.4461 & 0.0002 & 0.3575 & 0.6069 \\
Pre $\times$ S & 0.0002 & 0.6799 & 0.3110 & 0.2735 & 0.8680 & 0.4560 & 0.0505 \\
Post $\times$ S & 0.5343 & 0.4776 & 0.8683 & 0.2057 & 0.2707 & 0.8363 & 0.8767 \\
Post $\times$ Pre $\times$ S & 0.7914 & 0.8456 & 0.9883 & 0.5632 & 0.5449 & 0.5346 & 0.0844 \\
\hline
\end{tabular}

Table 6 ANOva table with $P$-values for the analysis of weed species density 
Table 7 Crop yield in untreated plots and predicted main effects of pre-emergence and post-emergence weed harrowing and the combined effect of pre- and post-emergence weed harrowing ( $95 \%$ confidence intervals in parentheses)

\begin{tabular}{|c|c|c|c|c|}
\hline \multirow[b]{2}{*}{ Experiment } & \multirow{2}{*}{$\begin{array}{l}\text { Grain yield } \\
\text { in untreated } \\
\text { plots }\left(\mathrm{t} \mathrm{ha}^{-1} \text { ) }\right.\end{array}$} & \multicolumn{3}{|l|}{ Yield increase (\%) } \\
\hline & & $\begin{array}{l}\text { Pre-emergence } \\
\text { harrowing }\end{array}$ & $\begin{array}{l}\text { Post-emergence } \\
\text { harrowing }\end{array}$ & Combined effect \\
\hline 1 & 3.21 & $10.3(1.8 \text { to } 18.1)^{*}$ & $17.3(9.4 \text { to } 24.4)^{* * *}$ & $25.8(13.7 \text { to } 36.3)^{* * *}$ \\
\hline 2 & 4.88 & $-2.4(-12 \text { to } 6.5)^{\mathrm{NS}}$ & $-4.6(-13.9 \text { to } 4.2)^{\mathrm{NS}}$ & $-7.4(-0.6 \text { to } 12.7)^{\mathrm{NS}}$ \\
\hline 3 & 5.06 & $0.7(-8.7 \text { to } 8.0)^{\mathrm{NS}}$ & $6.9(-2.0 \text { to } 14.9)^{\mathrm{NS}}$ & $7.7(-5.7 \text { to } 19.1)^{\mathrm{NS}}$ \\
\hline 4 & 1.25 & $35.2(28.1 \text { to } 41.1)^{* * *}$ & $12.1(2.8 \text { to } 20.6)^{*}$ & $42.7(30.1 \text { to } 53.0)^{* * *}$ \\
\hline 5 & 3.44 & $3.5(-6 \text { to } 12.6)^{\mathrm{NS}}$ & $-1.4(-11.6 \text { to } 7.6)^{\mathrm{NS}}$ & $2.1(-17.5 \text { to } 18.6)^{\mathrm{NS}}$ \\
\hline 6 & 5.69 & $-0.3(-11.6 \text { to } 10.4)^{\mathrm{NS}}$ & $7.1(-3.4 \text { to } 16.4)^{\mathrm{NS}}$ & $7.2(-1.4 \text { to } 15.2)^{\mathrm{NS}}$ \\
\hline 7 & 7.37 & $0.3(-8.7 \text { to } 8.9)^{\mathrm{NS}}$ & $0.3(-7.8 \text { to } 9.5)^{\mathrm{NS}}$ & $0.6(-6.0 \text { to } 6.9)^{\mathrm{NS}}$ \\
\hline 8 & 5.1 & $-5.5(-13.8 \text { to } 3.4)^{\mathrm{NS}}$ & $-6.6(-17.2 \text { to } 7.3)^{\mathrm{NS}}$ & $-13.2(-29.5 \text { to } 1.2)^{\mathrm{NS}}$ \\
\hline
\end{tabular}

$* P<0.05 ; * * P<0.01 ; * * * P<0.001 ;$ NS, non-significant $(P>0.05)$.

between pre- and post-emergence harrowing was expected, because pre-emergence weed harrowing is mainly effective against early germinating weeds, which are supposed to be the most difficult ones to control later on. Buhler et al. (1992) showed that pre-emergence cultivation with a rotary hoe increased the effectiveness of subsequent inter-row cultivations in soyabean (Glycine $\max (\mathrm{L}$.) Merr.), but apart from this report, it is difficult to find experimental support for the hypothesis. Rasmussen et al. (2012) showed that pre-emergence flame weeding had no impact on the efficiency of postemergence weed harrowing in sugar beets, even if flame weeding reduced the average weed size by $31 \%$. Neither pre-emergence flame weeding nor pre-emergence weed harrowing improved the efficacy of subsequent mechanical intra-row cultivation in vegetables (Melander, 1998; Melander \& Rasmussen, 2001). Therefore, the importance of pre-emergence weed control appears to be without practical importance for the efficiency of postemergence cultivation and the hypothesis that the combination of pre- and post-emergence harrowing gives more stable weed control effects than pre- and post-emergence weed harrowing used alone could not be supported.

A major challenge in weed harrowing is the considerable site-year variability often found (Navntoft et al., 2007). We also found that the efficacy of pre- and postemergence weed harrowing was highly dependent on site and year variations. We also found that the variability in pre- and post-emergence weed control effects was correlated across experiments. If pre-emergence harrowing for some site-specific reason gave a low weed control effect, post-emergence weed harrowing also gave a low effect and vice versa (Fig. 1). A similar site-specific correlation between the effects of repeated cultivations has also been reported by Navntoft et al. (2007). Our study cannot reveal the exact reasons, but the soil shear strength influenced the efficacy of the CMN harrow with strait tines, whereas weed species responded similarly to weed harrowing within each experiment (Table 6). This may suggest that soil properties play a key role in the site and year variation in experiments with weed harrowing. We found that bent tines resulted in higher weed control effects and were less influenced by hard-packed and/or crusted soil than harrowing with strait tines. However, one major drawback of bent tines, which was not investigated in the present studied, is that they bring more stones to the soil surface on stony soils than strait tines.

Another major challenge in weed harrowing is to understand and predict the relationship between cultivation intensity and crop yield response. Predictive models assume that the crop yield response to harrowing is a function of crop damage associated with harrowing and reduced weed competition (Rueda-Ayala et al., 2011). However, this study showed that weed harrowing also may have positive impacts on crop yield due to soil loosening. In Experiment 4, the combined effect of pre- and post-emergence harrowing increased crop yield by $43 \%$ (Table 7) even if weeds were considered without competitive ability. Experiment 4 was conducted in oats, which has been shown to less tolerant to weed harrowing than spring barley (Rasmussen et al., 2009), but the soil loosening effect totally overwhelmed this aspect.

In this study, it was decided to standardise driving speed and cultivation depth. It is likely that a more adaptive approach could have reduced the variability in weed control effects among experiments. In Rasmussen et al. $(2008,2009,2010)$, an adaptive approach to cultivation intensity was used, based on the idea that setting and use of a weed harrow should be adapted to the immediate crop and weed responses. A hard-packed clay soil requires more aggressive cultivation than a soft sandy soil, because it is difficult to bring packed heavy soil into motion, which is important for weed control. The majority of weeds are not killed by the tines themselves, but by the soil that the tines force into 
motion. In consequence, setting and use of the harrow should not be the same on different soils, if the adaptive approach is used. It is, however, unclear to what extent the variable weed control effects could have been stabilised by use of the adaptive approach to cultivation. It is also unclear how the approach should have been used in relation to pre-emergence weed harrowing, because crop and weed impact cannot be easily measured prior to crop and weed emergence.

The main purpose of this study was to investigate whether there was a positive interaction between preand post-emergence weed harrowing under different environmental conditions, and the answer is clear: no evidence of such an interaction was found. In consequence, one may ask whether pre-emergence weed harrowing is worthwhile? Would it be possible to achieve the same results with just one aggressive, postemergence cultivation as compared with two less aggressive cultivations carried out before and after crop emergence? Unfortunately, this question cannot be answered in this study and the literature offers little help if one wants to evaluate whether repeated cultivations with a certain time interval are better than one aggressive cultivation. Farmers seem to prefer repeated cultivations, but there is no scientific evidence that this is a preferable strategy. Hence, much still has to be learned about weed harrowing, to increase the knowledge base required to improve the performance of this widely-used method of weed control.

\section{References}

Andreasen C \& Streibig JC (2011) Evaluation of changes in weed flora in arable fields of Nordic countries - based on Danish long-term surveys. Weed Research 51, 214-226.

Buhler DD, Gunsolus JL \& RALston DF (1992) Integrated weed management-techniques to reduce herbicide inputs in soybean. Agronomy 84, 973-978.

Dierauer HU (1990) Versuchsmäßiger Geräteeinsatz und unterschiedliche Saatdistanz zur Verbesserung des Wirkungsgrades der mechanischen Unkrautregulierung im Getreide. Veröffentlichung der Bundesanstalt für Agrarbiologie Linz/Donau 20, 79-90.

Fylkesmannen i Oslo og Akershus (2011) Tilskudd til regionale miljøtiltak for landbruket i Oslo og Akershus 2011. Landbruksavdelingen, Fylkesmannen i Oslo og Akershus, Oslo, Norway, $20 \mathrm{pp}$.

Hyvönen T, Ketoja E, SAlonen J, Jalli H \& Tiainen J (2003) Weed species diversity and community composition in organic and conventional cropping of spring cereals. Agriculture, Ecosystems and Environment 97, 131-149.

Jensen RK, Rasmussen J \& Melander B (2004) Selectivity of weed harrowing in lupin. Weed Research 44, 245-253.

Johnson EN \& Holm FA (2010) Pre-emergence mechanical weed control in field pea (Pisum sativum L.). Canadian Journal of Plant Science 90, 133-138.
KeES H (1962) Untersuchungen zur Unkrautbekämpfung durch Netzegge und Stoppelbearbeitungsmaßnahmen. Dissertation, Universität Stuttgart-Hohenheim, Hohenheim, Germany.

Korsmo E (1926) Ogräs, Ogräsarternas liv och kampen mot dem i nutidens jordbruk. Albert Bonniers Förlag, Stockholm, Sweden.

Kurstjens DAG \& KropfF MJ (2001) The impact of uprooting and soil-covering on the effectiveness of weed harrowing. Weed Research 41, 211-228.

Leblanc ML \& Cloutier DC (2001) Susceptibility of rowplanted soybean (Glycine max) to the rotary hoe. Journal of Sustainable Agriculture 18, 53-61.

LUNDKVIST A (2009) Effects of pre- and post-emergence weed harrowing on annual weeds in peas and spring cereal. Weed Research 49, 409-416.

MAngerud K (2006) Veien til god ugrasharving. Norsk landbruk 125, 36-38.

Melander B (1998) Interactions between soil cultivation in darkness, flaming, and brush weeding when used for in-row weed control in vegetables. Biological Agriculture and Horticulture 16, 1-14.

Melander B \& Rasmussen G (2001) Effects of cultural methods and physical weed control on intrarow weed numbers, manual weeding and marketable yield in direct-sown leek and bulb onion. Weed Research 41, 491-508.

Navntoft S, Petersen BS, Esbjerg P et al. (2007) Effects of Mechanical Weed Control in Spring Cereals - Flora, Fauna and Economy. Danish Environmental Protection Agency, Copenhagen, Denmark (Pesticides Research No. 114 2007). Available at: http://www2.mst.dk/Udgiv/publications/2007/ 978-87-7052-555-8/pdf/978-87-7052-556-5.pdf (last accessed 10 December 2011).

RASMUSSEN J (1992) Testing harrows for mechanical control of annual weeds in agricultural crops. Weed Research 32, 267-274.

RAsmussen J (1996) Mechanical Weed Management. In: Second International Weed Control Congress (eds H Brown, GW Cussans, MD Devine et al.), 943-948. (25-28 June 1996), IWCC. Copenhagen, Denmark.

Rasmussen J, Bibby B \& Schou AP (2008) Investigating the selectivity of weed harrowing with new methods. Weed Research 48, 523-532.

Rasmussen J, Nielsen HH \& Gundersen H (2009) Tolerance and selectivity of cereal species and cultivars to postemergence weed harrowing. Weed Science 57, 338-345.

Rasmussen J, Griepentrog HW, Nielsen J \& Henriksen CB (2012) Automated intelligent rotor tine cultivation and punch planting to improve the selectivity of mechanical intra-row weed control. Weed Research 52, doi:10.1111/ j.1365-3180.2012.00922.x.

Rasmussen J, Mathiasen H \& BibBy BM (2010) Timing of postemergence weed harrowing. Weed Research 40, 436-446.

Rueda-Ayala V, Rasmussen J, Gerhards R \& Fournaise NE (2011) The influence of post-emergence weed harrowing on selectivity, crop recovery and crop yield in different growth stages of winter wheat. Weed Research 51, 478 488.

Rydberg T (1985) Ogräsharvning - en litteraturstudie. Rapport - Sveriges lantbruksuniversitet, Institutionen för 
Interactions between pre- and post-emergence weed harrowing $\mathbf{3 4 7}$

växtodling 154, SLU, Institutionen för växtodling (numera: SLU, Institutionen för växtodlingslära, Uppsala, Sweden.

Van Der Schans D, Bleeker P, Molendijk L et al. (2006) Practical Weed Control in Arable Farming and Outdoor

Vegetable Cultivation Without Chemicals. PPO publication
532 Applied Plant Research Wageningen University, Lelystad, the Netherlands, 77.

Zadoks JC, Chang TT \& Konzak CF (1974) Decimal code for growth stages of cereals. Weed Research 14, 415-421. 